\title{
Conventional and clumped isotopes in ecological research
}

\section{Abstract}

Stable isotope ratios at natural abundance levels are increasingly used in ecological studies. Common uses of stable isotopes in ecology include their use as biological tracers for source identifications, tracing nutrient and contaminant flows in food webs, identifying the geographic origin of migratory animals and birds, studying crosscontinental spread of infectious diseases, diet reconstruction of extinct animals, food authentication, study of photosynthesis by different types of plants, estimating $\mathrm{CO} 2$ emissions from different sources to the atmosphere and quantifying relative inputs in a system. Here we review some of the applications of stable isotopes in ecological and pale ecological studies. The review is restricted to the study of natural variations of the isotopes. Recently developed advanced stable isotope tools such as clumped and triple oxygen isotopes are also introduced in ecological studies. Potential of clumped isotopes to understand the thermal physiology of dinosaurs is discussed in this review.
Volume 2 Issue 4 - 2017

\author{
Amzad Hussain Laskar \\ Research Center for Environmental Changes, Academia Sinica, \\ Taiwan
}

Correspondence: Amzad Hussain Laskar, Research Center for Environmental Changes, Academia Sinica, Taipei, Taiwan, Tel +886 -265-398-85, Email amzadhussain2000@gmail.com

Received: May 09, 2017| Published: July 05, 2017

\section{Introduction}

Stable isotopic composition of carbon, nitrogen, oxygen and hydrogen are increasingly used in ecological and environmental studies. The advantage of stable isotope data in biogeochemical research is that they can contribute to both source-sink (tracer) and process information. They provide ecological information across a range of spatio-temporal scales, i.e. from cell to ecosystems, and across a time scale of seconds to millennia. ${ }^{1}$ With modern mass spectrometers isotopic compositions of natural materials can be measured with extremely high precision. As elements cycle through the biosphere, isotopic compositions change in predictable ways. These changes have been exploited by geochemists to understand the global elemental cycles. This review is to give a brief idea about the basic applications of stable isotopes in ecosystem studies. It is started with a brief description of the stable isotope measurement techniques along with the natural variations of the isotopic compositions of common elements. It is focussed mainly on $\mathrm{C}, \mathrm{O}, \mathrm{N}$ and $\mathrm{H}$ isotopic analysis. Also a potential application of a recently developed advanced technique viz. clumped isotope thermometry in ecosystem and pale ecology research has been discussed.

\section{Stable isotope terminology \\ measurements}

and

Isotopes of an element have the same number of protons but differ in their number of neutrons, resulting in different masses. There is variation in the relative abundances of the isotopes. The lighter isotopes generally form weaker bonds than the heavier ones and tend to react faster causing a slight difference in their relative abundances in different phases and in the products of different chemical and physical processes. This change in the isotopic abundance is called fractionation. Different environments are often characterized by predictable isotopic signatures. Stable isotopes are measured in mass spectrometers as isotopic ratios and are expressed as isotopic deviations from standards, denoted by delta $(\delta)$ values as parts per thousand or per mil denoted by \%o. The $\delta$ values are calculated as follows:

$$
\delta \mathrm{X}=\left[\left(\mathrm{R}_{\text {sample }} / \mathrm{R}_{\text {standard }}\right)-1\right] \times 1000
$$

Where $\mathrm{X}$ is the isotope (such as ${ }^{13} \mathrm{C}$ and ${ }^{15} \mathrm{~N}$ ), and $\mathrm{R}$ is the corresponding isotope ratio $\left({ }^{13} \mathrm{C} /{ }^{12} \mathrm{C}\right.$ or $\left.{ }^{15} \mathrm{~N} /{ }^{14} \mathrm{~N}\right)$. The quotient of the ratios in the sample relative to the standard is the $\delta$ value. Each element has a primary international standard with a $\delta$ value of $0 \%$. Deviations towards the positive and negative imply enrichments and depletions in the heavy isotope respectively, with respect to the standard. Measurements are carried out in gas phase; samples are converted into gases and purified before introducing into the mass spectrometer. The precision of measurements varies from gas to gas. With modern mass spectrometers, precisions better than $0.1 \%$ o is easily achievable for $\delta^{13} \mathrm{C}$ and $\delta^{18} \mathrm{O}$. Anomaly in ${ }^{17} \mathrm{O}$ in $\mathrm{CO}_{2}$ is another recently introduced tracer and is mostly used to identify the sources of $\mathrm{CO}_{2}{ }^{2-5}$ It is the deviation of $\delta$-values of a sample from the mass-dependent fractionation line expressed by $\Delta^{17} \mathrm{O}=\ln \left(1+\delta^{17} \mathrm{O}\right)$ $\lambda \times \ln \left(1+\delta^{18} \mathrm{O}\right)$. The factor $\lambda$ vary between 0.500 and 0.529 depending on different fractionation process. ${ }^{6}$ With recently developed analytical techniques, $\Delta^{17} \mathrm{O}$ can be measured with a precision better than $0.01 \%$. Similar to ${ }^{17} \mathrm{O}$, clumped isotopes in $\mathrm{CO}_{2}$ (excess of mass 47 , mainly ${ }^{13} \mathrm{C}^{18} \mathrm{O}^{16} \mathrm{O}$ over a random distribution of isotopes, denoted by $\Delta_{47}$ ) is another powerful tracer and can be used to identify the sources of $\mathrm{CO}_{2} \cdot{ }^{7} \Delta_{47}$ is defined by

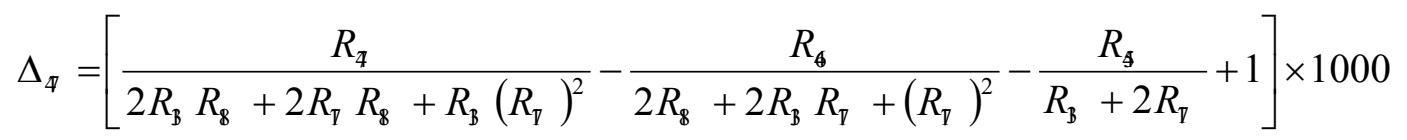


where $\mathrm{R}_{13}$ and $\mathrm{R}_{18}$ (ratios ${ }^{13} \mathrm{C} /{ }^{12} \mathrm{C}$ and ${ }^{18} \mathrm{O} /{ }^{16} \mathrm{O}$ ) are obtained by measuring the traditional masses 44,45 and 46 in the same $\mathrm{CO}_{2}$ sample and $\mathrm{R}_{17}$ is calculated assuming a mass dependent relation with $\mathrm{R}_{18}$ (for details, see. ${ }^{7-10} \Delta_{47}$ can be measured with a precision better than $0.01 \%$.

\section{Common stable isotopes and their natural variations in ecosystems}

\section{Stable carbon isotopes}

Carbon has two naturally occur ring stable isotopes: ${ }^{12} \mathrm{C}$ and ${ }^{13} \mathrm{C}$ with abundances of $98.93 \%$ and $1.07 \%$ respectively. The carbon isotopic composition $\left(\delta^{13} \mathrm{C}\right)$ is expressed with respect to international standard Vienna Pee Dee Belemnite (VPDB) derived from a Cretaceous cephalopod (PDB). $\delta^{13} \mathrm{C}$ in natural samples can have variations of several tens of per mils with very negative values in biogenic methane and other reduced carbon compounds to marine carbonates with around zero values. One of the seminal discoveries in stable isotope ecology was differential discrimination during photosynthesis by different kind of plants. ${ }^{11}$ About $85 \%$ of plants follow Calvin cycle or $\mathrm{C} 3$ cycle (most of the big plants and cool season temperate plants) with $\delta^{13} \mathrm{C}$ in the range of -34 to $-20 .{ }^{12,13}$ Less than $0.5 \%$ plants follow Hatch-Slack cycle or $\mathrm{C} 4$ cycle (tropical warm grasses, sugarcane, sorghum etc.) with $\delta^{13} \mathrm{C}$ in the range of -9 to $-19 \%$. ${ }^{14} \mathrm{~A}$ third kind of photosynthetic pathway called Crassulacean Acid Metabolism or CAM (grow in dry environments such as cacti and pineapples) with intermediate $\delta^{13} \mathrm{C}$ between $\mathrm{C} 3$ and $\mathrm{C} 4$ plants consists of $\sim 10 \%$ of the plants. ${ }^{15}$ The difference in carbon isotopic composition is caused by the fact that the ribulose-1,5-bisphosphate carboxylase (Rubisco) catalyst, involved in the $\mathrm{C} 3$ pathway strongly discriminates against ${ }^{13} \mathrm{CO}_{2}$ compared to phosphoenolpyruvate (PEP) carboxylase, the $\mathrm{C} 4$ catalyst. Carbon isotopes cannot be used to distinguish CAM from $\mathrm{C} 4$ plants because of their similarity. However, evidences suggest that the CAM plants are considerably enriched in deuterium relative to source water. Therefore, hydrogen isotopic composition $(\delta \mathrm{D})$ is an important tracer to distinguish CAM plants from $\mathrm{C} 3$ and $\mathrm{C} 4$ plants $^{16-20}$ which traditionally was done by anatomical methods, specifically succulence (CAM) vs. Kranzanatomy (C4). More details about the applications of hydrogen isotopic composition are given in a later section.

Soil organic matter reflects the type of vegetative cover present in a given soil. ${ }^{21-25} \mathrm{~A}$ simplified diagram of the distribution of $\delta^{13} \mathrm{C}$ in ecosystems is shown in Figure $1 . \delta^{13} \mathrm{C}$ is also widely used for predicting the origin of diets through time and across space. ${ }^{26-30}$ This is because animals are similar in isotopic compositions to their diets for carbon but heavier by $3-5 \%$ from dietary nitrogen. Thoughstable isotope ratios do not reproduce exact menu, but broadly help to constrain food categories such as, meat versus plants, terrestrial versus aquatic protein sources and C4grasses/cereals versus $\mathrm{C} 3$ fruits/vegetables. ${ }^{31-33}$ Figure 2 gives a brief idea of the isotopic variation in the food web of terrestrial and aquatic plants. Study of human diets in ancient settings is a key to understand the Cultural revolution and human modification with time in ancient ecosystems. Stable isotopes in the fossil bone collagen, teeth enamel, bipartite and eggshell carbonate are useful to study the ancient human diets. Understanding the diet and nutrition is carried out by analysing stable isotope along with other physiological factors which influence the stable isotope ratios in the body. This helps our understanding of health and nutrition over a broad range of contexts. $^{34-38}$

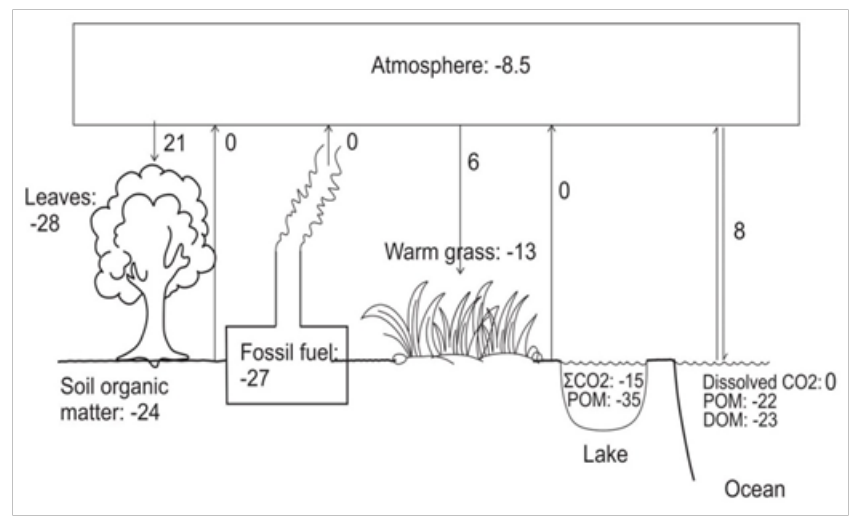

Figure I: Carbon isotopic distribution in ecosystems, the numbers in various reservoirs is their approximate $\delta^{13} \mathrm{C}$ values in \%

$\mathrm{CO}_{2}$ fluxes are shown by single arrows; the numbers next to the arrows are the approximate fractionations during the transfer of $\mathrm{CO}_{2}$. Double arrow indicates equilibrium fractionation. POM, particulate organic matter; DOM, dissolved organic matter. $2,7,12,13,22,24,34-38$

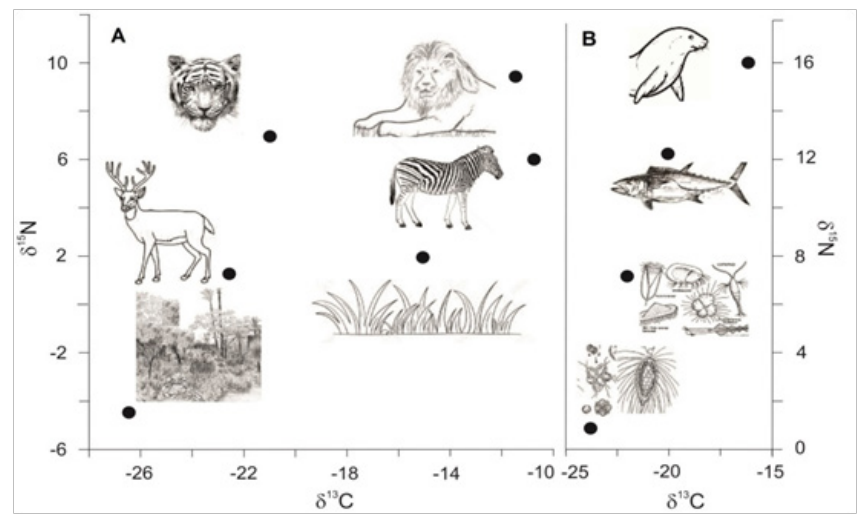

Figure 2 A simplified diagram showing trophic enrichment in carbon and nitrogen isotopic compositions from primary producers to herbivores to predators for (A) Terrestrial ecosystem and (B) Marine ecosystem. For terrestrial ecosystem, food chain starting with both $C 3$ and $C 4$ plants as primary producers are shown. ${ }^{57}$

\section{Stable nitrogen isotope}

Nitrogen is mainly present as $\mathrm{N}_{2}$ gas in the atmosphere with $\delta^{15} \mathrm{~N}$ of $0 \%$. Stable isotope studies of nitrogen are helpful in identifying the sources and fates of N.Nitrogen isotopes fractionate during primary uptake. Based on their source of nitrogen, plants may be divided into two types: those can utilize $\mathrm{N}_{2}$ directly, and those utilize only "fixed" nitrogen as ammoniaand nitrate. The former include the legumes (e.g., beans, peas) and marine cyanobacteria.Very little nitrogen isotopic fractionation takes place during direct fixation of $\mathrm{N}_{2}$ from atmosphere and hence $\delta^{15} \mathrm{~N}$ values for such plants are close to zero $\left[\right.$ e.g. ${ }^{39,40}$ ]. The legumes, which are exclusively $\mathrm{C}_{3}$ plants, utilize both $\mathrm{N}_{2}$ and fixed nitrogen (though symbiotic bacteria) have average $\delta^{15} \mathrm{~N}$ value of $+1 \%$. ${ }^{41,42}$ Marine plants have $\delta^{15} \mathrm{~N}$ valueof $5-10 \%$ and marine cyanobacteria have $\delta^{15} \mathrm{~N}$ of $-1 \pm 3 \%{ }^{43-45}$ Through biological $\mathrm{N}_{2}$ fixation, assimilation atmospheric $\mathrm{N}_{2}$ into $\mathrm{NH}_{3}$ by some specific microorganisms is a key process for the atmospheric $\mathrm{N}_{2}$ to enter into terrestrial ecosystem. ${ }^{46}$ There is a wide range of isotopic values for nitrogen in ammonia and nitrate. ${ }^{47}$ Therefore, Non-nitrogen-fixing 
plants have a more varying range of $\delta^{15} \mathrm{~N}$ values depending on their source of nitrogen. However, very little is known about the $\mathrm{N}_{2}$ isotopic fractionation during assimilation of organic form of nitrogen. Plants can be slightly enriched or depleted in ${ }^{15} \mathrm{~N}$ compared to the $\mathrm{NO}_{3}$ source ${ }^{48}$ probably due to release of nitrogen fractionated compounds. ${ }^{49}$ Successive oxidations steps in nitrification are associated with varying amounts of kinetic fractionations. Most of the organic nitrogen in soils is slowly converted into ammonium, the rate-determining step in the nitrification process and the resulting nitrate is quite similar in terms of $\delta^{15} \mathrm{~N}$ to the organic starting materials. However, when large amounts of ammonium are available, the oxidation steps to nitrite and nitrate are rate limiting, and the nitrate formed may be very depleted in ${ }^{15} \mathrm{~N}$. Nitrogen isotopic fractionation may be induced by high external NO concentrations, osmotic stress, or drought, although the mechanisms for this fractionation are still not known very well. ${ }^{50,51}$ On average modern nonleguminous plants have average $\delta^{15} \mathrm{~N}$ value a few per mil higher than the atmospheric $\mathrm{N}_{2}{ }^{1} \delta^{15} \mathrm{~N}$ values of different plant parts can differ by 2-3\%o but can be as high as $7 \%$ in desert plants [52]. Isotope label experiments such as supplying ${ }^{15} \mathrm{~N}$ enriched nitrate compound and following its fate can be a way to differentiate between external and internal plant sources and to quantify the importance of the internal cycling of nitrogen. Dual-isotope (say ${ }^{13} \mathrm{C}$ and ${ }^{15} \mathrm{~N}$ ) is also a powerful tool to demonstrate the relationship between internal $\mathrm{N}$ stores and recently fixed photosynthate ${ }^{53}$

Denitrification back to molecular nitrogen gas involves large ${ }^{15} \mathrm{~N}$ depletion. ${ }^{54}$ All the fractionations in the pedospheric part of the nitrogen cycle are heavily dependent on nitrogen concentrations. Synthetic fertilisers, since being produced from air via the Haber process, are close to $0 \%{ }^{55}$ Volatilisation of ammonium compounds to ammonia from manure, however, involves a fractionation of up to $-40 \%$, such that the residue may be very enriched in ${ }^{15} \mathrm{~N}$. Figure 2 shows changes in carbon and nitrogen isotopic compositions in terrestrial and marine food chain.A comprehensive review of nitrogen isotope fractionations in plants and soils can be found in Högberg. ${ }^{56}$

\section{Stable oxygen and hydrogen isotopes}

Oxygen isotopic composition $\left(\delta^{18} \mathrm{O}\right)$ is widely used for partitioning net $\mathrm{CO}_{2}$ terrestrial fluxes between soil respiration and that exchange with plant leaves, the exchange rate is enhanced by catalytic action of carbonic anhydrase in plants and soils. ${ }^{57-64}$ This is because the $\delta^{18} \mathrm{O}$ of $\mathrm{CO}_{2}$ fluxes originated from soil respiration are different from that exchanged with leaf water. $\delta^{18} \mathrm{O}$ in soil water reflect the $\delta^{18} \mathrm{O}$ value of meteoric water but the leaf water is relatively enriched due to transpiration. As the $\delta^{18} \mathrm{O}$ values from these processes and interactions are different, therefore, this tracer is widely used for constraining the gross production of $\mathrm{CO}_{2}{ }^{58,61,64-66} \delta^{18} \mathrm{O}$ in ecosystems are also used for identifying the source of water. It can be used for phosphate sources in aquatic ecosystems by measuring the $\delta^{18} \mathrm{O}$ values in dissolved inorganic phosphates. ${ }^{67} \delta^{18} \mathrm{O}$ in phosphates, bioaptites, tooth enamels and eggshell carbonates are widely used to reconstruct the drinking water of extinct species such as dinosaurs. ${ }^{68,69}$

Stable hydrogen isotopic composition $(\delta \mathrm{D})$ is very useful to study the origin of migratory animals specifically birds as there is geographical pattern of $\delta \mathrm{D}$ in the precipitation. It is observed that the $\delta \mathrm{D}$ values in bird's feathers are correlated with the $\delta \mathrm{D}$ values of the precipitation and hence this isotope proxy is widely used for assigning origin of migratory birds [e.g., ${ }^{70-73}$ Though $\delta$ Dhasso far been restricted mainly to studies of migratory origin and pale climate reconstruction based on systematic relationships between organism tissue and local environmental water, it can be used to study modern food webs as demonstrated recently. The large $\delta \mathrm{D}$ differences between aquatic and terrestrial ecosystem end members can be utilized for the quantification of energy inputs and nutrient fluxes between these two sources. ${ }^{74}$ Particularly $\delta \mathrm{D}$ can be used for determining allochthonous vs. autochthonous nutrient sources in freshwater systems. Some studies also suggested that $\delta$ Dhas relation with trophic position and this marker may be used as a trophic indicator, in addition to the more commonly used $\delta^{15} \mathrm{~N}$. Coupled measurements of $\delta^{2} \mathrm{H}$ and $\delta^{18} \mathrm{O}$ values are increasing as a result of advancement of precise analytical techniques to measure both simultaneously, which may provide additional ecological information over single element measurements.

\section{Triple oxygen and clumped isotopes}

$\mathrm{CO}_{2}$ in the atmosphere has many sources and sinks with diverse fluxes. Because of this diversity and variability, it is always not possible to constrain the sources and sinks using conventional isotope data. For example, it is not possible to distinguish $\mathrm{CO}_{2}$ emitted from fossil fuel burning and respired $\mathrm{CO}_{2}$ from $\mathrm{C} 3$ plants or soil under $\mathrm{C} 3$ vegetation cover as $\delta^{13} \mathrm{C}$ value of the two sources are similar. Similarly, rapid exchange of oxygen isotopes between $\mathrm{CO}_{2}$ and different water reservoirs with diverse $\delta^{18} \mathrm{O}$ and processes such as vapor transpiration complicate its interpretation. ${ }^{75}$ In such cases triple oxygen and clumped isotopes can be very useful. ${ }^{2,76}$ Plant and soil respired $\mathrm{CO}_{2}$ has $\Delta^{17} \mathrm{O}$ value close to zero while $\mathrm{CO}_{2}$ from combustion sources has negative $\Delta^{17} \mathrm{O}$ making it ideal for distinguishing the two sources. $\Delta \Delta^{17} \mathrm{O}$ in stem and leaf waters in plants has also been found to be very useful to understand transpiration processes under different relative humidity condition. ${ }^{4}$ Clumed isotope $\left(\Delta_{47}\right)$ values of $\mathrm{CO}_{2}$ depend on the formation temperature of the $\mathrm{CO}_{2}$. When $\mathrm{CO}_{2}$ interacts with water, $\Delta_{47}$ value of the $\mathrm{CO}_{2}$ gets modified depending on the temperature of the water. At thermodynamic equilibrium, $\mathrm{CO}_{2}$ is expected to reflect the temperature at which exchange takes place. ${ }^{77,78}$ Thus the fluxes that involve $\mathrm{CO}_{2}$ equilibration with water have $\Delta_{47}$ as expected at thermodynamic equilibrium. Similar to $\Delta^{17} \mathrm{O}, \Delta_{47}$ is also very useful to distinguish $\mathrm{CO}_{2}$ originated from respiration and combustion. Also $\Delta_{47}$ is found to be sensitive to photosynthesis making it suitable to study photosynthesis also. ${ }^{7}$ Triple oxygen isotopic data in biogenic carbonates (eggshell carbonates, bioapatite and tooth enamels) are useful to study influence of evaporation and metabolic waterin animal body. ${ }^{79-81}$ A strong environmental and physicological control on body water $\Delta^{17} \mathrm{O}$ has been observed for modern mammals and birds. ${ }^{81}$ Therefore, this could be used for pale environmental and pale ecological reconstruction. Clumped isotopes in carbonates directly give the temperature of precipitation. Therefore, clumped isotope analysis in biologically precipitated apatite in bone, teeth and eggshell carbonates can shed light on the thermal physiology of extinct animals such as dinosaurs ${ }^{82-84}$ which was previously carried out indirectly. ${ }^{82-92}$

\section{Some applications of stable isotopes in ecological and paleoecological problems}

Applications of stable isotopes in ecological research are very diverse.Some specific examples of the applications of a few selected stable isotopes are given below.

\section{Stable carbon and nitrogen isotopes in determining animal's diet}

Stable isotope analysis is very useful to trace modern and extinct animal's diet. Stable isotope gives information of diet integrated over 
a longer time period and offers an alternative approach which is often nondestructive and in many cases noninvasive. Animals are similar in isotopic compositions to their diets for carbon, but on average 3 to $5 \%$ o heavier than dietary nitrogen. Diet-switching experiments for carbon clearly show that the diet is the primary determinant of animal isotopic compositions. ${ }^{93-96}$ For example, gerbils that were switched from corn diet $\left(\delta^{13} \mathrm{C}=-12 \%\right)$ to wheat-based $\operatorname{diet}\left(\delta^{13} \mathrm{C}=\right.$ $-22 \%$ ) approached the wheat carbon isotopic composition with time though the turnover times are different in different tissues. ${ }^{96}$ The fastest change was observed in liver (half-life 6.4 days) and slowest in hair (half life 47.5 days). Thisis also true for nitrogen, with the caveat that animals are somewhat enriched in ${ }^{15} \mathrm{~N}$ compared its value in diet and the magnitude of the difference is relatively consistent among organisms..$^{97-100}{ }^{15} \mathrm{~N}$ enrichments versus diet are found to be related to processes of nitrogen assimilation and excretion. More detail discussion regarding this enrichment can be found in previous works [e.g., ${ }^{99,101,102}$ ].

\section{Variation of atmospheric $\mathrm{CO} 2$ levels using stable isotopes in tree rings}

$\mathrm{CO}_{2}$ is the main greenhouse and its rapid increase in the atmosphere in the industrial era is the central point of the concern for climate scientists. For any mitigation strategy, it needs proper understanding the sources of $\mathrm{CO}_{2}$. The relative contribution of $\mathrm{CO}_{2}$ from combustion of fossil fuels and from oxidation of forest and soil organic matter particularly due to deforestation and land-use changes has been debated. ${ }^{103,104}$ While history of $\mathrm{CO}_{2}$ emitted from fossil fuel combustion is known very well, the timing and amount of $\mathrm{CO}_{2}$ released from the terrestrial organic matter is not known well. The terrestrial contribution of $\mathrm{CO}_{2}$ to the atmosphere can be estimated using models and ${ }^{13} \mathrm{C}$ changes with time in the past.

Addition of $\mathrm{CO}_{2}$ from the fossil fuel combustion with average $\delta^{13} \mathrm{C}$ value of $\sim-27 \% 0^{2}$ and oxidation of terrestrial organic matter with average $\delta^{13} \mathrm{C}$ value of $\sim-28 \% 0^{22,25}$ has lowered the overall $\delta^{13} \mathrm{C}$ value of the atmospheric $\mathrm{CO}_{2}$. As the amount of fossil fuel burned at different times is well known, it is possible to calculate the amount of $\mathrm{CO}_{2}$ released to the atmosphere by terrestrial biomass in the past, particularly during the industrial period. The model needs accurate time course of atmospheric $\delta^{13} \mathrm{C}$ values as the $\mathrm{CO}_{2}$ continuously exchanges with oceanic and biospheric carbon. Tree rings can provide accurate $\delta^{13} \mathrm{C}$ values in the atmosphere in the past. A major advantage with tree rings is that they can be precisely dated with annual or even seasonal time resolution. ${ }^{105}$ Though there is variation in the $\delta^{13} \mathrm{C}$ values from tree to tree, overall a decrease of $\delta^{13} \mathrm{C}$ by $1.8 \%$ has been recorded from the beginning of the industrial period $(\sim 1750 \mathrm{CE})$ to the year $2000 \mathrm{CE} .{ }^{106}$ Analysis of atmospheric $\mathrm{CO}_{2}$ trapped in polar ice core air have supported the timing and magnitude of atmospheric $\delta^{13} \mathrm{C}$ changes deduced from tree ring analysis. ${ }^{107,108}$ Variation in the $\delta^{13} \mathrm{C}$ values derived from tree rings during the last $\sim 250$ years is shown in Figure 3A. ${ }^{109}$ The variation in atmospheric $\mathrm{CO}_{2}$ concentration derived from polar ice core during the same period is shown in Figure 3B. A significant decline in the $\delta^{13} \mathrm{C}$ values was observed during 1800 s, well before the upswing of the fossil fuel use. This has been attributed to long-term and large-scale release of $\mathrm{CO}_{2}$ depleted in ${ }^{13} \mathrm{C}$ due to clearing and burning of forests and oxidation of soil organic matter (with $\delta^{13} \mathrm{C}$ value of $\sim-28 \%$ ). However, expected increase in the corresponding $\mathrm{CO}_{2}$ concentration is not very obvious probably because of the dampening of the signal in the polar region and coarser resolution of ice core data. The recent rapid decrease in $\delta^{13} \mathrm{C}$ correlates with the increase in fossil fuel use. An obvious conclusion is that the release of $\mathrm{CO}_{2}$ from terrestrial carbon stocks to the atmosphere was greatest during 1800-1920 AD. A steady decrease in the $\delta^{13} \mathrm{C}$ values between 1920 to $1960 \mathrm{AD}$ was caused by both terrestrial and fossil fuel burned $\mathrm{CO}_{2}$. Model calculations showed that the contribution of $\mathrm{CO}_{2}$ to the atmosphere from the two sources is comparable until 1980 AD: $\sim 140 \times 10^{9}$ tons from biosphere and $170 \times 10^{9}$ tons from fossil fuel combustion. ${ }^{110}$ The sharp decline in $\delta^{13} \mathrm{C}$ and increase in $\mathrm{CO}_{2}$ concentration post 1960 was mainly due to ever increasing rate fossil fuel combustion.

This example illustrates the usefulness of isotope tracers in paleoecology and climate change research. Alternative methods of calculating the loss of biospheric carbon through analysis of landuse patternsand deforestation are not very accurate due to the lack of accurate historical land-use records. More than one independent methods of computingchanges in biospheric carbon stocks $\left(\delta^{13} \mathrm{C}\right.$ versus historical land use records) is important considering the importance of properunderstanding of thecontrols of atmospheric $\mathrm{CO}_{2}$ levels. ${ }^{111}$
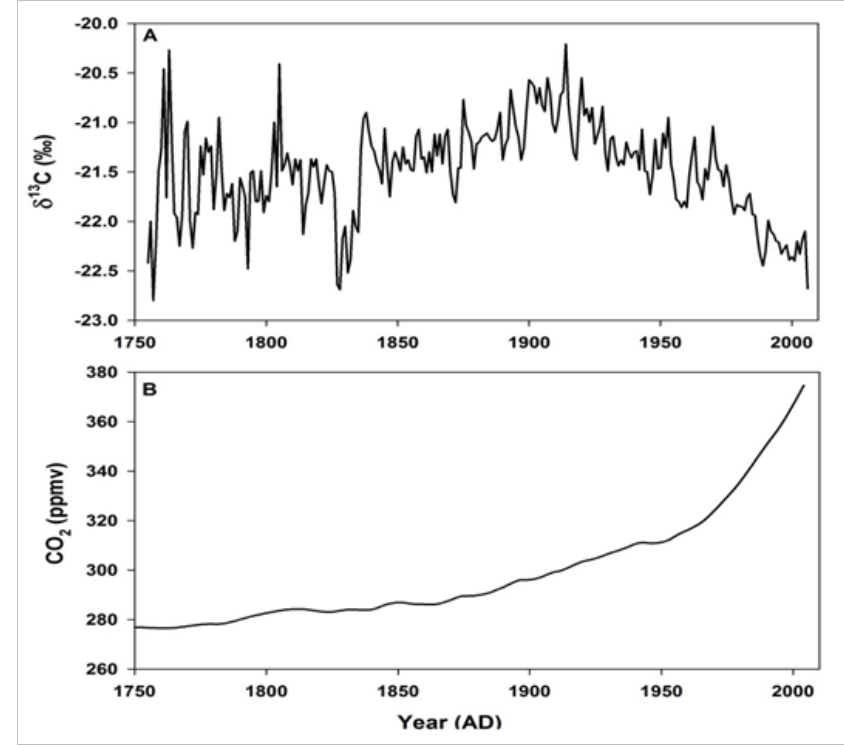

Figure 3A Stable carbon isotopic composition $\left(\square^{13} \mathrm{C}\right)$ derived from African tree ring. 109

Figure 3B Atmospheric $\mathrm{CO}_{2}$ concentration during the industrial period (from 1750 to 2010 AD) derived from Law Dome Ice Core,Antarctica." ${ }^{\prime \prime}$

(Source: World Data Service for Pale climatology, Boulder and NOAA Pale climatology Program National Centers for Environmental Information (NCEI)).

\section{Identifying the geographic origin of migratory birds}

Stable isotopes in animal keratins including hair, claw, skin, nail, horn, baleen and feathers have been increasingly used for studying animal migration. ${ }^{57,72,112}$ Keratin is metabolically inert and once formed, the chemical composition including its isotopic signature reflects the environmental conditions under which it was developed. If an animal molts in one location and then migrates across any of the isotope landscapes, the isotopic signature held in keratin becomes a migratory tag that can be used to predict where that animal was when the keratin grew. Since the pioneering studies by Best and Schell 
(1996), ${ }^{113}$ Chamberlain et al. (1997) ${ }^{114}$ and Hobson and Wassenaar $(1997)^{115}$ using stable isotopes to track migration by identifying systematic geographic pattern in the isotope signatures in tissues from wild animal populations, stable isotopes have been widely used to elicit spatiotemporal structure in patterns of mammalian migration in both marine ${ }^{113,116,117}$ and terrestrial ${ }^{118}$ systems. Stable hydrogen isotopes $(\delta \mathrm{D})$ are useful to study patterns of migration and connectivity for birds ${ }^{119}$ and bats. ${ }^{120} \delta \mathrm{D}$ hasalso been widely used in humanforensics applications. ${ }^{121,122}$ The main reason behind the use of these isotopes to study migration is that, these isotopes in general have predictable compositions over a geographic region and follow some patterns with geographical and other ecologically meaningful gradients. However, it is not straightforward to assign the geographic origin of migratory animal using isotopes because of many complicacies such as assigning isotopic values to a given region by measurements or interpolation and the variation of the isotopic composition in different individuals in a given location. Therefore, multiple isotope proxies are often better in assigning the geographic origins [e.g., $\left.{ }^{73,123}\right]$.

The most important step for using stable isotopes for tracking animal migration is to calibrate an assignment model to link isotopes and geography using tissues of known origin (Wunder and Norris 2008). This is done either using sample data of a region without defining any mechanisms for predicting isotope values of the region ${ }^{124,125}$ or smoothed or interpolated patterns that generate predicted results across the full range of spatial scales for possible geographic locations [e.g. ${ }^{126}$ ]. Wunder et al. ${ }^{73}$ used feathers of known origin collected across the breeding range of migratory mountain plover to test the use of isotope tracers for assigning breedingorigins. One year data was used to generate the model and next year data to test the model performance. They analyzed $\delta^{13} \mathrm{C}, \delta^{15} \mathrm{~N}$ and $\delta \mathrm{D}$ in feathers of the bird and observed a systematic variation of $\delta \mathrm{D}$ in the feathers with latitude variation of 6 to 9 degree indicating that hydrogen isotopes in birds feathers is a good tracer for studying the origin of migratory birds. However, no strong systematic $\delta^{13} \mathrm{C}$ variation in the feathers with latitude was observed. This is due to combination of $\mathrm{C} 3$ and $\mathrm{C} 4$ vegetation used by mountain plovers. Probably local vegetation, geography and demography affects the $\delta^{13} \mathrm{C}$ values more than regional to continental effects as demonstrated by Graves et al. ${ }^{127}$ Nitrogen isotopic composition $\left(\delta^{15} \mathrm{~N}\right)$ in plover's feather showed a systematic variation with latitude. Inverse regression model was found to be inappropriate to assign latitudinal origin of the birds, instead they used the probability density estimated from data generated in 2001 to assign the geographic origin of the birds from the data generated in 2002. Combined isotopic data were found to better assign of the geographic origin of the bird than that predicted by any of the single or double isotope data. Caccamise et al. $^{71}$ carried out measurements of carbon, nitrogen and sulphur isotopic compositions on newly grown feathers in birds of known origin in a single year.The sample groupings were stratified across clear discrimination gradients in the three studied isotopes and they reported a $92 \%$ correct assignment rate. Hobson et al. ${ }^{72}$ showed that $\delta \mathrm{D}$ and $\delta^{18} \mathrm{O}$ in feathers of mmigratory birds in Europe are useful to track their origin and movements. Wassenaarand Hobson (2000) ${ }^{128}$ correctly classified $80 \%$ oftheir data among 11 locations that spanned discriminationgradients in carbon and hydrogen isotopes even though the feathers werecollected and pooled over a 17-year period from uncertain locations. Royle et al. ${ }^{129}$ pooled feathers for 10 years from uncertain origins and categorised into three vast geographic regions, eachrepresented by three collection sites. Using carbon and hydrogen isotopes, $62 \%$ of the observationswere assigned to the correct region.

With availability of more spatially resolved isotopic data, the assignment of the geographic origin of birds is becoming more accurate. It is relatively straightforward to convert isotopic cluster pattern to other tissue isocapes (bone collagen, hair, muscle) by applying the appropriate discrimination factors. Similarly, our understanding of isotopic discrimination factors linking feathers to food web or precipitation baselines are likely to improve over time with new research and better techniques which would help to revise the mean tissue values associated with the isotopic clusters. Another potential means to adopt a multivariate approach is to combine stable isotope analysis with trace element profiles of feathers or hair to trace the origin of birds. Trace elements in feathers reflect that of the soil substrate where feathers were grown. With analytical advancements, fingerprinting individuals using trace elements is gaining interests and a combined study would provide better means to trace the origin of individuals.

\section{Clumped isotopes to constrain thermal physiology of dinosaurs}

The body temperatures of dinosaurs provides crucial information in tracing biological evolution of thermoregulation. Since the discovery of dinosaurs in $1842 \mathrm{CE}$, there has been discussion about the nature of their body metabolism, particularly whether they were endothermic or ectothermic. Initially dinosaurs were believed to be ectothermic similar to modern day reptiles that derive heat from the environment to maintain their body temperatures, in contrast to endothermic mammals and birds which maintain almost a stable body temperature by internal metabolic heat production. In the later part of the $20^{\text {th }}$ century, evidences in support of the endothermic metabolism started emerging from observations of their behavior, pale geographic distribution, and anatomy of non-avian dinosaurs. ${ }^{85,130,131}$ Until recent time the thermal physiology of non-avian dinosaurs, especially the endothermic/ectothermic nature of their metabolism were inferred indirectly using body mass, biophysical modeling, bone histology, and growth rate through assumptions which remain highly debated. Clumped isotope thermometry, based on the thermodynamically driven preference of ${ }^{13} \mathrm{C}-{ }^{18} \mathrm{O}$ bond in carbonate minerals of fossilized bioapatites, tooth enamels and eggshells allows a direct measurement of their body temperatures, providing a new window in understanding the thermoregulations of the extinct oviparous species. The advantage of clumped isotopes is that the isotope signature $\left({ }^{13} \mathrm{C}-{ }^{18} \mathrm{O}\right.$ bond abundance) in carbonate lattice is dependent on the precipitation temperature only, unlike conventional stable isotope paleo-thermometers such as oxygen isotope thermometry which is dependent on the temperature of precipitation as well as the isotopic composition of water from which the mineral formed. It is found that the ${ }^{13} \mathrm{C}-{ }^{18} \mathrm{O}$ bond abundances in the carbonate component of tooth bioapatite and eggshell carbonate from modern specimens follow the same relationship between isotope clumping and temperature and can reproduce the body temperature with accuracy better than $2^{\circ} \mathrm{C}$. This thermometer is being applied to constrain the thermal physiology of extinct species such as dinosaur and this is the first direct measurements of their body temperatures. The main concern is to ensure that the fossilized material were not altered, called digenetic alteration during their burial. Such alterations of ${ }^{13} \mathrm{C}-{ }^{18} \mathrm{O}$ bond ordering 
are possible through dissolution/re-precipitation reactions associated with intrusion of secondary carbonate solution. However, it is possible to check the preservation of eggshell carbonates subsequent to their burial. Usually Scanning electron microscope (SEM) analysis is carried out on the carbonates to check if the primary cell structure remained unchanged, an evidence of the preservation of samples. Another test is to measure the isotopic composition including clumped isotopes in the sample and the host rock. For well preserved samples, a significant difference in the isotopic values between the samples and host rock is expected. Simple plot between $\delta^{13} \mathrm{C}$ and $\delta^{18} \mathrm{O}$ is also used to check their preservation: for altered samples a significant correlation is expected as the alteration may effect both the isotopes simultaneously.

Eagle et al. ${ }^{84}$ measured Clumped isotope values $\left(\Delta_{47}\right)$ in Late Cretaceous titanosaurid eggshells collected from three different sites: the Nemegt Basin, Mongolia, Auca Mahuevo in Neuquén Province, Argentina and the Provence Basin in France to estimate their body temperatures. Before applying the clumped isotope thermometry to fossil eggshells of dinosaurs, they verified the clumped isotope thermometry with modern eggshells by measuring the $\Delta_{47}$ values in the eggshell carbonates and comparing the actual body temperatures for a series of modern oviparous animals. They observed $\Delta_{47}$ values in the range of 0.65 to $0.67 \%$ for well-preserved eggshells of the Late Cretaceous dinosaur species. These values give dinosaur body temperatures in the range of 30 to $35^{\circ} \mathrm{C}$. The highest body temperature is comparable to the body temperature of modern mammal but on average $\sim 6^{\circ} \mathrm{C}$ less than modern birds implying that this tax on did not have thermoregulation comparable to modern birds, but was able to elevate its body temperature above environmental temperatures. Therefore, they concluded that probably dinosaurs cannot be categorised to any of the end-member ectothermy or endothermy but maintained a variable thermoregulation. Similar conclusion could be drawn from their previous analysis of clumped isotopes in bio minerals. ${ }^{82,83}$ For a better constrain on the thermoregulation of this extinct species, more clumped isotope analysis on well preserved eggshells with wide spatial distribution is required. More such analysis from other groups are expected to come in future which will not only help to constrain the thermoregulation of this extinct species but also their evolution and extinction. ${ }^{130,131}$

\section{Conclusion}

Stable isotopes distributions in natural systems reflect an integrated history of physical and metabolic processes within ecosystems and are very useful for a wide variety of ecosystem studies. This review provided information on how stable isotopes can be used to various aspects of ecological research. The discussion is limited to applications of some selected isotopes. Additional measurements of some more stable isotopes such as sulphur and strontium are found to be useful in some circumstances though not discussed in this review. Clearly, the combination of several independent isotopic tracers shows the greatest promise in addressing an ecosystem problem. Advancements in analytical techniques especially precise measurements of multiplysubstituted isotopes has open a new horizon for addressing many more ecological and paleo-ecological problems such as thermoregulation of dinosaurs as discussed in this review. Another recently established clumped isotope proxy in methane may help to constrain its formation particularly, to distinguish biogenic methane from thermogenic origin.

\section{Acknowledgements}

The author is thankful to Dr. Aylen Green for inviting to contribute an article in the Journal MOJ Ecology and Environmental Science.

\section{Conflict of interest}

The author declares no conflict of interest.

\section{References}

1. Dawson TE, Mambelli S, Plamboeck AH, et al. Stable isotopes in plant ecology. Annual Review of Ecology and Systematics. 2002;33:507-559.

2. Laskar $\mathrm{AH}$, Mahata S, Liang MC. Identification of anthropogenic $\mathrm{CO}_{2}$ using triple oxygen and clumped isotopes. Environmenatl Science and Technology. 2016;50(21):11806-11814.

3. Liang MC, Mahata S, Laskar AH, et al. Spatiotemporal variation of oxygen isotope anomaly in near surface $\mathrm{CO} 2$ over urban, semiurban and ocean in and around Taiwan. Aerosol and Air Quality Research. 2016;17:706-720.

4. Landais, Barka E, Yakir D, Luz B. The triple isotopic composition of oxygen in leaf water. Geochim Cosmochim Acta. 2006;70(16):4105-4115.

5. Thiemens MH, Chakraborty S, Jackson TL. Decadal $\Delta^{17} \mathrm{O}$ record of tropospheric $\mathrm{CO}_{2}$ : Verification of a stratospheric component in the troposphere. J Geophys Res. 2014;119(10):6221-6229.

6. Thiemens MH. Mass-independent isotope effects in planetary atmospheres and the early solar system. Science. 1999;283(5400):341-345.

7. Laskar AH, Liang MC. Clumped isotopes in near surface atmospheric $\mathrm{CO}_{2}$ over land, coast and ocean in Taiwan and its vicinity. Biogeosciences. 2016;13:5297-5314

8. Ghosh ${ }^{\text {P. }}{ }^{13} \mathrm{C}-{ }^{18} \mathrm{O}$ bonds in carbonate minerals: a new kind of paleothermometer. Geochim Cosmochim Acta. 2006;70(6):1439-1456.

9. Huntington KW, Eiler JM, Affek HP, et al. Methods and limitations of 'clumped' $\mathrm{CO}_{2}$ isotope $\left(\Delta_{47}\right)$ analysis by gas-source isotope ratio mass spectrometry. J Mass Spectrom. 2009;44(9):1318-1329.

10. Laskar AH, Yui TF, Liang MC. Clumped isotope composition of marbles from the backbone range of Taiwan. Terra Nova. 2006;28(4):265-270.

11. Smith BN, Epstein $\mathrm{S}$. Two categories of ${ }^{13} \mathrm{C} /{ }^{12} \mathrm{C}$ ratios for higher plants. Plant Physiol. 1971;47(3):380-384.

12. Deines P. The isotopic composition of reduced organic carbon. In P Fritz, JC Fontes (Eds.), Handbook of Environmental Isotope Geochemistry. The Terrestrial Environment. 1980;1:329-406.

13. Kohn MJ. Carbon isotope compositions of terrestrial C3 plants as indicators of (paleo) ecology and (paleo) climate. Proc Natl Acad Sci USA. 2010;107(46):19691-19695

14. Farquhar GD, Ehleringer JR, Hubick KT. Carbon isotope discrimination and photosynthesis. Annu Rev Plant Physiol Plant Mol Biol. 1989;40:503537.

15. Cernusak LA, Ubierna N, Winter K, et al. Environmental and physiological determinants of carbon isotope discrimination in terrestrial plants. New Phytologist. 2013;200(4):950-965.

16. Ziegler H. Hydrogen isotope fractionation in plant tissues. In PW Rundel, JR Ehleringer, et al. editors. Stable Isotopes in Ecological Research. Germany: Springer; 1988. p. 105-123.

17. Sternberg LSL, DeNiro MJ. Biogeochemical implications of the isotopic equilibrium fractionation factor between the oxygen atoms of acetone and water. Geochimicaet Cosmochimica Acta. 1983;47(12):2271-2274. 
18. Sternberg L, Deniro MJ, Ajie H. Stable hydrogen isotope ratios of saponifiable lipids and cellulose nitrate from cam, C-3 and C-4 plant. Phytochemistry. 1984;23:2475-2477.

19. Sternberg LO, DeNiro MJ, Johnson HB. Isotope ratios of cellulose from plants having different photosynthetic pathways. Plant Physiol. 1984;74:557-561.

20. Sternberg LSL. Oxygen and hydrogen isotope ratios in plant cellulose: Mechanisms and applications. In PW Rundel, JR Ehleringer, et al. editors. Stable Isotopes in Ecological Research. Verlag Berlin, Germany: Springer; 1988. p. 124-141.

21. Laskar AH, Sharma N, Ramesh R, et al. Paleoclimate and paleogegetation of Lower Narmada Basin, Gujarat, Western India, inferred from stable carbon and oxygen isotopes. Quaternary International. 2010;227(2):183189.

22. Laskar AH, Yadava MG, Ramesh R, et al. Late Holocene climate and organic carbon turnover in the Lower Narmada valley, Gujarat, Western India, inferred using sedimentary carbon and oxygen isotope ratios. The Holocene. 2013;23(8):1115-1122.

23. Laskar AH. Stable and radioactive carbon in India soils: implications to soil carbon dynamics. Udaipur (unpublished), India: Ph D thesis to Mohanlal Sukhadia University; 2012.

24. Laskar AH, Yadava MG, Ramesh R. Radiocarbon and stable carbon isotopes in two soil profiles from North-East India. Radiocarbon. 2012;54 (1):81-89.

25. Laskar AH, Yadava MG, Ramesh R. Stable and radioactive carbon in forest soil of Chhattisgarh, Central India: implications for tropical soil carbon dynamics and stable carbon isotope evolution. J Asian Earth Sci. 2016;123(1):47-57.

26. Lee-Thorp JA, van der Merwe NJ. Carbon isotope analysis of fossil bone apatite. South African Journal of Science. 1987;83:712-715.

27. Bocherens $\mathrm{H}$, Koch $\mathrm{P}$, Mariotti $\mathrm{A}$, et al. Isotopic biogeochemistry $\left({ }^{13} \mathrm{C},{ }^{18} \mathrm{O}\right)$ of mammalian enamel from African Pleistocene hominid sites. Palaios. 1996;11:306-318.

28. Cerling TE, Harris JM, Ambrose SH, et al. Dietary and environmental reconstruction with stable isotope analyses of herbivore tooth enamel from the Miocene locality of Fort Ternan, Kenya. J Hum Evol. 1997;33(6):635650 .

29. Sponheimer M, Lee-Thorp JA. Isotopic evidence for the diet of an early hominid, Australopithecus africanus. Science. 1999;283(5400):368-370.

30. Klein RG. Stable carbon isotopes and human evolution. Proceedings of the National Academy of Sciences. 2013;110(26):10470-10472.

31. Nehlich O, Fuller BT, Jay M, et al. Application of sulphur isotope ratios to examine weaning patterns and freshwater fish consumption in Roman Oxfordshire, UK. Geochim Cosmochim Acta. 2011;75(17):4963-4497.

32. Schoeninger MJ, DeNiro MJ. Nitrogen and carbon isotopic composition of bone collagen from marine and terrestrial animals. Geochimica et Cosmochimica Acta. 1984;48(4):625-639.

33. Hemer KA, Lamb AL, Chenery CA, et al. A multi-isotope investigation of diet and subsistence amongst island and mainland populations from early medieval western Britain. Am J Phys Anthropol. 2017;162:423-440.

34. Anderson TF, Arthur MA. Stable isotopes of oxygen and carbon and their application to sedimentologic and paleo environmental problems. In MA Arthur, et al. editors. Stable Isotopes in Sedimentary Geology. Soc Econ Paleontol Mineral; 1983. p. 1-151.

35. Fry B, Sherr EB. $\delta^{13} \mathrm{C}$ measurements as indicators of carbon flow in marine and freshwater ecosystems. Collfrib Mar Sci. 1984;27:13-47.
36. O'Leary MH. Carbon isotope fractionation in plants. Phytochemistry. 1981;20(4):553-567.

37. Schwarcz HP. Isotopes in nature. I. The stable isotopes of carbon. In KH Wedepohl editors. Handbook of Geochemistry II-I. 1969;6B:1-16.

38. Williams PM, Gordon LI. Carbon- 13: carbon- 12 ratios in dissolved and particulate organic matter in the sea. Deep-Sea Res. 1970;17(1):19-27.

39. Doughton JA, Vallis I, Saffigna PG. An indirect method for estimating ${ }^{15} \mathrm{~N}$ isotope fractionation during nitrogen fixation by a legume under field conditions. Plant and Soil. 1992;144(1):23-29.

40. Unkovich M. Isotope discrimination provides new insight into biological nitrogen fixation. New Phytol. 2013;198(3):643-646.

41. Kohl DH, Shearer G. Isotopic fractionation associated with Symbiotic $\mathrm{N}_{2}$ fixation and uptake of $\mathrm{NO}_{3}$ by Plants. Plant Physiol. 1980;66(1):51-56.

42. Perkins MJ, McDonald RA, van Veen FJF, et al. Application of Nitrogen and Carbon Stable Isotopes $\left(\delta^{15} \mathrm{~N}\right.$ and $\left.\delta^{13} \mathrm{C}\right)$ to Quantify Food Chain Length and Trophic Structure. PLOS ONE. 2014;9(3):e93281.

43. Cline JD, Kaplan IR. Isotopic fractionation of dissolved nitrate during denitrification in the eastern tropical north Pacific Ocean. Mar Chern. 1975;3(4):271-299.

44. Miyake Y, Wada E. The abundance ratio of ' $5 \mathrm{~N} /$ ' $4 \mathrm{~N}$ in marine environments. Rec Oceanogr Works Jpn. 1967;9:37-53.

45. Cloern JE, Canuel EA, Harris D. Stable carbon and nitrogen isotope composition of aquatic and terrestrial plants of the San Francisco Bay estuarine system. Limnology and Oceanography. 2002;47(3):713-729.

46. Vitousek PM, Cassman K, Cleveland C, et al. Towards an ecological understanding of biological nitrogen fixation. Biogeochemistry. 2002;57(1): $1-45$.

47. Amundson R, Austin AT, Schuur EAG, et al. Global patterns of the isotopic composition of soil and plant nitrogen. Global Biogeochem Cycles. 2003;17(1):1031.

48. Yoneyama T, Matsumaru T, Usui K, et al. Discrimination of nitrogen isotopes during absorption of ammonium and nitrate at different nitrogen concentrations by rice (Oryza sativa L.) plants. Plant Cell Environ. 2001;24(1):133-139.

49. Robinson D, Handley LL, Scrimgeour CM. A theory for ${ }^{15} \mathrm{~N} /{ }^{14} \mathrm{~N}$ fractionation in nitrate-grown vascular plants. Planta. 1998;205(3):397406.

50. Handley LL, Odee D, Scrimgeour CM. $\delta^{15} \mathrm{~N}$ and $\delta^{13} \mathrm{C}$ patterns in savanna vegetation: dependence on water availability and disturbance. Funct Ecol. 1994;8:306-314.

51. Handley LL, Robinson D, Forster BP, et al. Shoot delta N correlates with genotype and salt stress in barley. Planta. 1997;201:100-102.

52. Evans RD. Physiological mechanisms influencing plant nitrogen isotope composition. Trends Plant Science. 2001;6(3):121-126.

53. Dyckmans J, Flessa H. Influence of tree internal $\mathrm{N}$ status on uptake and translocation of $\mathrm{C}$ and $\mathrm{N}$ in beech: a dual $13 \mathrm{C}$ and $15 \mathrm{~N}$ labelling approach. Tree Physiol. 2001;21(6):395-401.

54. Martin TS, Casciotti KL. Nitrogen and oxygen isotopic fractionation during microbial nitrite reduction. Limnol Oceanogr. 2016;61(3):1134 1143 .

55. Michalski G, Kolanowski M, Riha KM. Oxygen and nitrogen isotopic composition of nitrate in commercial fertilizers, nitric acid, and reagent salts. Isotopes Environ Health Stud. 2015;51(3):382-391.

56. Hoegberg P. ${ }^{15} \mathrm{~N}$ natural abundance in soil-plant systems. New Phytologist. 1997;137(2):179-203. 
57. Ben-David M, Flaherty EA. Stable isotopes in mammalian research: a beginner's guide. Journal of Mammalogy. 2012;93(2):312-328.

58. Francey RJ, Tans PP. Latitudinal variation in O-18 of atmospheric $\mathrm{CO}_{2}$. Nature. 1987;327:495-497.

59. Farquhar GD, Lloyd J. Carbon and oxygen isotope effects in the exchange of carbon dioxide between plants and the atmosphere. In JR Ehleringer, et al. editors. Stable isotopes and plant carbon-water relations. New York, USA: Academic Press; 1993. p. 47-70.

60. Yakir D, Wang XF. Fluxes of $\mathrm{CO}_{2}$ and water between terrestrial vegetation and the atmosphere estimated from isotope measurements. Nature. 1996;380:515-517.

61. Ciais P, Denning AS, Tans PP, et al. A three-dimensional synthesis study of $\delta^{18} \mathrm{O}$ in atmospheric $\mathrm{CO}_{2}$. 1. Surface fluxes. J Geophys Res Atm. 1997;102(D5):5857-5872.

62. Peylin $\mathrm{P}$, Ciais $\mathrm{P}$, Denning AS, et al. A 3-dimensional study of $\delta^{18} \mathrm{O}$ in atmospheric $\mathrm{CO}_{2}$ : contribution of different land ecosystems. Tellus Series B-Chemical and Physical Meteorology. 1999;51(3):642-667.

63. Murayama S, Takamura C, Yamamoto S, et al. Seasonal variations of atmospheric $\mathrm{CO}_{2}, \delta^{13} \mathrm{C}$, and $\delta^{18} \mathrm{O}$ at a cool temperate deciduous forest in Japan: Influence of Asian monsoon. J Geophys Res. 2010;115(D17).

64. Welp LR, Keeling RF, Meijer HAJ, et al. Interannual variability in the oxygen isotopes of atmospheric $\mathrm{CO}_{2}$ driven by El Nino. Nature. 2011;477:579-582.

65. Gillon J, Yakir D. Influence of carbonic anhydrase activity in terrestrial vegetation on the ${ }^{18} \mathrm{O}$ content of atmospheric $\mathrm{CO}_{2}$. Science. 2001;291(5513):2584-2587.

66. Cuntz M, Ciais P, Hoffmann G, et al. A comprehensive global threedimensional model of $\delta^{18} \mathrm{O}$ in atmospheric $\mathrm{CO}_{2}$ : 2. Mapping the atmospheric signal. J Geophys Res. 2003;108:(D17).

67. Young MB, McLaughlin K, Kendall C, et al. Characterizing the oxygen isotopic composition of phosphate sources to aquatic ecosystems. Environ Sci Technol. 2009;43(14):5190-5196.

68. Sarkar A, Bhattacharya SK, Mohabey DM. Stable-isotope analyses of dinosaur eggshells: Paleoenvironmental implications. Geology. 1991;19(11):1068-1071.

69. Sponheimer M, Lee-Thorp J A. The oxygen isotope composition of mammalian namel carbonate from Morea Estate, South Africa. Oecologia. 2001;126(2):153-157.

70. Wassenaar LI, Hobson KA. A stable-isotope approach to delineate geographical catchment areas of avian migration monitoring stations in North America. Environ Sci Technol. 2001;35(9):1845-1850.

71. Caccamise DF, Reed LM, Castelli PM, et al. Distinguishing migrant and resident Canada geese using stable isotope analysis. Journal of Wildlife Management. 2000;64:1084-1091.

72. Hobson KA, Wassenaar LI, Bowen GJ, et al. Using stable hydrogen and oxygen isotope measurements of feathers to infer geographical origins of migrating European birds. Oecologia. 2004;141(3):477-488.

73. Wunder MB, Kester L, Knopf FL, et al. A test of geographic assignment using isotope tracers in feathers of known origin. Oecologia. 2005;144(4):607-617.

74. Vander Zanden HB, Soto DX, Bowen GJ, et al. Expanding the isotopic toolbox: applications of hydrogen and oxygen stable isotope ratios to food web studies. Front Ecol Evol. 2016;4:1-19.

75. Riley WJ, Still CJ, Helliker BR, et al. ${ }^{18} \mathrm{O}$ composition of $\mathrm{CO}_{2}$ and $\mathrm{H}_{2} \mathrm{O}$ ecosystem pools and fluxes in a tallgrass prairie: simulations and comparisons to measurements. Global Change Biol. 2003;9(11):15671581 .
76. Affek HP, Eiler JM. Abundance of mass $47 \mathrm{CO}_{2}$ in urban air, car exhaust, and human breath. Geochim. 2006;70(2006):1-12.

77. EilerJM,Schauble E. ${ }^{18} \mathrm{O}^{13} \mathrm{C}^{16} \mathrm{O}$ in Earth's atmosphere. Geochim Cosmochim Acta. 2004;68(23):4767-4777.

78. Wang Z, Schauble EA, Eiler JM. Equilibrium thermodynamics of multiply substituted isotopologues of molecular gases. Geochim Cosmochim Acta. 2004;68(23):4779-4797.

79. Gehler A, Tutken T, Pack A. Triple oxygen isotope analysis of bioapatite as tracer for diagenetic alteration of bones and teeth. Palaeogeogr Palaeoclim Palaeoecol. 2011;310(1-2):84-91.

80. Pack A, Gehler A, Sussenberger A. Exploring the usability of isotopically anomalous oxygen in bones and teeth as a paleo- $\mathrm{CO}_{2}$-barometer. Geochim Cosmochim Acta. 2013;102(1):306-317.

81. Passey B, Hu H, Ji H, et al. Triple oxygen isotopes in biogenic and sedimentary carbonates. Geochimicaet Cosmochimica Acta. 2014;141:125 .

82. Eagle RA, Edwin A Schauble, Aradhna K Tripati, et al. Body temperatures of modern and extinct vertebrates from ${ }^{13} \mathrm{C}-{ }^{18} \mathrm{O}$ bond abundances in bioapatite. Proc Nat Acad Sci. 2010;107(23):10377-10382.

83. Eagle RA. Dinosaur body temperatures determined from isotopic $\left({ }^{13} \mathrm{C}-{ }^{18} \mathrm{O}\right)$ ordering in fossil biominerals. Science. 2011;333(6041):443-445.

84. Eagle RA. Isotopic ordering in eggshells reflects body temperatures and suggests differing thermophysiology in two Cretaceous dinosaurs. Nature Communications. 2015. 6 p.

85. Bakker RT. Anatomical and ecological evidence of endothermy in dinosaurs. Nature. 1972;238:81-85.

86. Farlow JO. Dinosaur Energetics and Thermal Biology. In DB Weishampel, et al. efitors. The Dinosauria. 1st ed. USA: University of California Press; 1990. p. 43-55.

87. Ostrom JH. The evidence for endothermy in dinosaurs. In RDK Thomas, et al. editors. A Cold look at the Warm-Blooded Dinosaurs; 1980 p. 15-54.

88. O'Conner MP, Dodson P. Biophysical constraints on the thermal ecology of dinosaurs. Paleobiology. 1999;25:341-368.

89. Seebacher F. Dinosaur Body Temperatures: The Occurrence of Endothermy and Ectothermy. Paleobiology. 2003;29:105-122.

90. Pontzer H, Allen V, Hutchinson JR. Biomechanics of Running Indicates Endothermy in Bipedal Dinosaurs. Plos One. 2009;4:e7783.

91. Sander PM, Christian A, Clauss M, et al. Biology of the sauropod dinosaurs: the evolution of gigantism. Biological Reviews. 2011;86(1):117-155.

92. Ruben JA, Leitsch A, Hillenius WJ, et al. New insights into the metabolic physiology of dinosaurs. In JO Farlow, et al. editors.) The Complete Dinosaur. India: Bloomington: Indiana Univ Press; 1997. p. 505-518.

93. Folinsbee RE, Fritz P, Krouse HR, et al. Carbon-13 and oxygen-18 in dinosaur, crocodile, and bird eggshells indicate environmental conditions. Science. 1970;168:1353-1356.

94. LaCroix M, Mosora F. Variations du rapport isotopique $13 \mathrm{C} / 12 \mathrm{C}$ dansIemetabolisme animal. Isotope Ratios as Pollutant Source and Behaviour Indicators. Atomic Energy Agency. 1975. p. 343-358.

95. Fry B, Arnold C. Rapid $13 \mathrm{C} / 12 \mathrm{C}$ turnover during growth of brown shrimp (Penaeus a Zlccus). Oecologia.1982;54:200-204.

96. Tieszen LL, Boutton TW, Tesdahl KG, et al. Fractionation and turnover of stable carbon isotopes in animal tissues: Implications for $\mathrm{d} 13 \mathrm{C}$ analysis of diet. Oecologia. 1983;57:32-37.

97. Gaebler OH, Vitti TG, Vukmirovich R. Isotope effects inmetabolism of $14 \mathrm{~N}$ and $15 \mathrm{~N}$ from unlabeled dietary proteins. Can J Biochem. 1996;44(9):1249-1257. 
98. DeNiro MJ, Epstein S. Influence of diet on the distribution of nitrogen isotopes in animals. Geochim Cosmochim Acta. 1981;45(3):341-351.

99. Minagawa M, Wada E. Stepwise enrichment of $15 \mathrm{~N}$ along food chains: further evidence and the relation between $\mathrm{d} 15 \mathrm{~N}$ and animal age. Geochim Cosmochim Acta. 1984;48:1135-1140.

100. Smit AJ. Source identification in marine ecosystems: food web studies using $\mathrm{d} 13 \mathrm{C}$ and $\mathrm{d} 15 \mathrm{~N}$. In MJ Unkovich \& JS Pate, et al. editors. Stable isotope techniques in the study of biological processes and functioning of ecosystems. Dordrecht: Kluwer Academic; 2001. p. 219-245.

101. Steele KW, Daniel, RM. Fractionation of nitrogen isotopes by animals: A further complication to the use of variations in the natural abundance of ${ }^{15} \mathrm{~N}$ for tracer studies. A Rric Sci. 1978;90:7-9.

102. Vanderklift MA, Ponsard S. Sources of variation in consumer-diet d15N enrichment: a meta-analysis. Oecologia. 2003;136(2):169-182.

103. Hobbie JE, Cole J, Dungan I, et al. The controversy on the role of the biota in the global $\mathrm{CO}_{2}$ balance. BioScience. 1984;34(8):492-498.

104. Van der Werf GR, Morton DC, et al. $\mathrm{CO}_{2}$ emissions from forest loss. Nature Geoscience. 2009;2:737-738.

105. Managave SR, Sheshshayee MS, BorgaonkarHP, et al. Past break-monsoon conditions detectable by high resolution intra-annual $\delta^{18} \mathrm{O}$ analysis of teak rings. Geophys Res Lett. 2010;37(5).

106. Wang W, Liu X, Shao X, et al. A 200 year temperature record from tree ring $\delta^{13} \mathrm{C}$ at the Qaidam Basin of the Tibetan Plateau after identifying the optimum method to correct for changing atmospheric $\mathrm{CO}_{2}$ and $\delta^{13} \mathrm{C} . J$ Geophys Res. 2011;116(4).

107. Tans PP, Mook WG. Past atmospheric $\mathrm{CO}_{2}$ levels and the ${ }^{13} \mathrm{C} /{ }^{12} \mathrm{C}$ ratios in tree rings. Tellus. 1980;32(2):268-283.

108. Friedli $\mathrm{H}$, Loetscher $\mathrm{H}$, Oeschger $\mathrm{H}$, et al. Ice core record of the ${ }^{13} \mathrm{C} /{ }^{12} \mathrm{C}$ ratio of atmospheric $\mathrm{CO}_{2}$ in the past two centuries. Nature. 1986;324:237238.

109. Wils THG, Robertson I, Woodborne S, et al. African \$\$ 250 Year $\delta^{13} \mathrm{C}$ and intrinsic water-use efficiency (iWUE. world data service for paleoclimatology, Boulder and NOAA Paleoclimatology Program national centers for environmental information (NCEI); 2016.

110. Peng TH, Freyer HD. Revised estimates of atmospheric $\mathrm{CO}_{2}$ variations based on the tree-ring DC record. In JR Trabalka, et al. editors. The Changing Carbon Cycle: A Global Analysis. New York, USA: 1986. p. $151-159$.

111. Etheridge DM. Law Dome Ice Core 2000-Year $\mathrm{CO}_{2}, \mathrm{CH}_{4}$, and $\mathrm{N}_{2} \mathrm{O}$ Data. IGBP PAGES/World Data Center for Paleoclimatology Data Contribution Series \# 2010-070. NOAA/NCDC Paleoclimatology Program, Boulder CO, USA: 2010.

112. HobsonKA, WassenaarLI. Tracking animal migration with stable isotopes. Vol. 2.Terrestrial Ecology. San Diego, California, USA: Elsevier Inc; 2008.

113. BestPB, SchellDM. Stable isotopes in southern right whale (Eubalaenaaustralis) baleen as indicators of seasonal movements, feeding and growth. Marine Biology. 1996;124(4):483-494.

114. Chamberlain CP, Blum JD, Holmes RT, et al. The use of isotope tracers for identifying populations of migratory birds. Oecologia . 1997;109(1):132141.
115. Hobson KA, Wassenaar LI. Linking breeding and wintering grounds of Neotropical migrant songbirds using stable hydrogen isotopic analysis of feathers. Oecologia. 1997;109(1):142-148.

116. Lee SH, Schell DM, McDonald TL, et al. Regional and seasonal feeding by bowhead whales (Balaenamysticetus) as indicated by stable isotope ratios. Marine Ecology Progress Series. 2005;285:271-287.

117. Witteveen BH, Worthy GAJ, Roth JD. Tracing migratory movements of breeding North Pacific humpback whales using stable isotope analysis. Marine Ecology Progress Series. 2009;393:173-183.

118. Cerling TE. Stable isotopes in elephant hair document migration patterns and diet changes. Proceedings of the National Academy of Sciences. 2006;103(2):371-373.

119. Inger R, Bearhop S. Applications of stable isotope analysis to avian ecology. Ibis. 2008;150(3):447-461.

120. Britzke ER, Loeb SC, Hobson KA, et al. Using hydrogen isotopes to assign origins of bats in the eastern United States. Journal of Mammalogy. 2009;90(3):743-751.

121. Ehleringer JR, Bowe GJ, Chesson LA, et al. Hydrogen and oxygen isotope ratios in human hair are related to geography. Proceedings of the National Academy of Sciences. 2008;105(5):2788-2793.

122. Fraser I, Meier-AugensteinW, KalinRM. The role of stable isotopes in human identification: a longitudinal study into the variability of isotopic signals in human hair and nails. Rapid Communications in Mass Spectrometry. 2006;20(7):1109-1116.

123. Chamberlain CP, Bensch S, Feng X, et al. Stable isotopes examined across a migratory divide in Scandinavian willow warblers (Phylloscopustrochilustrochilus and Phylloscopustrochilusacredula) reflect their African winter quarters. Proceedings of Royal Society of London Series B-Biological Science. 2000;267(1438):43-48.

124. Wunder MB, Norris DR. Analysis and design for isotope-based studies of migratory animals. In KA Hobson,et al. editors. Tracking animal migration using stable isotopes. San Diego, California, USA: Elsevier; 2008. p. 107-128.

125. Wunder MB, Jehl JR, Stricker CA. The early bird gets the shrimp: confronting assumptions of isotopic equilibrium and homogeneity in a wild bird population. Journal of Animal Ecology. 2012;81(6):1223-1232.

126. Hobson KA, Atwell L,Wassenaar LI. Influence of drinking water and diet on the stable-hydrogen isotope ratios of animal tissues. Proceedings of the National Academy of Sciences. 1999;96(14):8003-8006.

127. Graves GR,Romanek CS, Navarro AR. Stable isotope signature of philopatry and dispersal in a migratory songbird. Proc Natl Acad Sci USA. 2002;99(12):8096-8100.

128. Wassenaar LI, Hobson KA. Improved method for determining the stablehydrogenisotopic composition $(\delta \mathrm{D})$ of complex organic materials of environmental interest. Environ Sci Technol. 2000;34:2354-2360.

129. Royle JA, Rubenstein DR. The role of speciesabundance in determining the breeding origins of migratorybirds using stable isotopes. Ecological Applications. 2004;4:1780-1788.

130. RussellLS. Body temperature of dinosaurs and its relationships to their extinction. Journal of Paleontology. 1965;39(3):497-501.

131. De Ricqlès AJ. Evolution of endothermy: Histological evidence. Evol Theory. 1974;1:51. 